Prawne i ekonomiczne aspekty imigracji do Polski, red. Magdalena Butrymowicz,

Piotr Kroczek, Kraków 2017, s. 57-69 (Biblioteczka Prawa, 2).

DOI: http://dx.doi.org/10.15633/9788374386340.05

Jan Mazur OSPPE

UNIWERSYTET PAPIESKI JANA PAWŁA II W KRAKOWIE

\title{
Imigracyjny kontekst polskiej polityki społecznej: dylematy i wyzwania
}

Wypada rozpocząć od krótkiej uwagi wyjaśniającej. Otóż dlaczego problem imigracji został skojarzony z polityka społeczną? Odpowiedź nie nastręcza większych trudności. Polityka społeczna stanowi bowiem naturalny kontekst - tak badawczy, jak i praktyczny - dla zagadnień związanych z polityką migracyjną czy całą problematyką migracyjną. W tym miejscu warto przynajmniej wspomnieć, że $\mathrm{w}$ teoretycznym dyskursie na temat migracji, a więc także i imigracji, do zadań polityki społecznej przeważnie zalicza się wyrównywanie szans życiowych migrantów oraz asekurowanie ich w nowym miejscu pobytu, jak również ułatwienie im integracji z miejscową ludnością. Innymi słowy, polityka migracyjna, uważana za jeden $z$ istotnych elementów polityki społecznej, winna troszczyć się o jak najlepsze warunki życia migrantów, świadczyć im pomoc w znalezieniu pracy, 
podejmować inicjatywy i działania zmierzające do ich asymilacji, adaptacji oraz integracji z nowym otoczeniem ${ }^{1}$.

Niniejsze rozważania stanowią próbę spojrzenia na dylematy i wyzwania, które stają przed polityką społeczną w związku z coraz bardziej widocznym w Polsce zjawiskiem imigracji. Tytułem uściślenia trzeba od razu zaznaczyć, że imigracja stanowi rodzaj migracji zagranicznej, zewnętrznej, która wymaga przekroczenia granicy państwowej, „przybycia” do państwa, w którym jest się cudzoziemcem. W sensie słownikowym oznacza napływ ludności obcej do jakiegoś kraju w celu osiedlenia się, względnie - podjęcia pracy zarobkowej².

Dziś w Polsce największym problemem migracyjnym jest masowa emigracja. Stanowi ona swego rodzaju kwestię społeczną (kwestię emigracyjną), co dla polityki społecznej jest niemałym wyzwaniem. Niemniej jednak emigracji towarzyszy imigracja. W Polsce nie stanowi ona wprawdzie kwestii społecznej, w przeciwieństwie do wielu krajów Unii Europejskiej, np. Niemiec czy Francji, ale budzi niepokój i rodzi potrzebę czujności ze strony polityki społecznej.

W ogólności można mówić o imigracjach wahadłowych, czasowych (okresowych), jak również definitywnych. Aktualnie polska

1 Por. A. Rajkiewicz, Polityka społeczna wobec procesów migracyjnych, w: Polityka społeczna. Podręcznik akademicki, red. G. Firlit-Fesnak, M. Szylko-Skoczny, Warszawa 2009, s. 303-313.

2 Zob. Słownik wyrazów obcych PWN, red. J. Tokarski, Warszawa 1980, s. 289; M. Sokólski, Imigracja, w: Encyklopedia PWN, http://encyklopedia.pwn.pl/haslo/ imigracja;3914293.html (22.11.2016). W ramach imigracji wyróżnia się rozmaite rodzaje imigrantów, m.in. imigrantów zarobkowych, uchodźców czy „nachodźców”. Imigranci to cudzoziemcy osiedlający się w danym kraju. W przypadku własnych obywateli państwa mówi się o migracji powrotnej, niekiedy też o reemigracji. Jeśli migracja powrotna jest zorganizowana przez administrację państwa lub inne instytucje publiczne, wówczas jest określana mianem repatriacji, choć może być podobna do klasycznej imigracji, np. w sytuacji zmiany granicy państwa. W niniejszym szkicu nie ma potrzeby wychodzenia poza znaczenie słownikowe tych terminów, gdyż wydaje się, że kontekst rozważań jest wystarczająco jasny. 
polityka społeczna musi się zmierzyć z dwiema kategoriami imigrantów. Pierwszą kategorię tworzą imigranci z byłych republik Związku Sowieckiego, przede wszystkim z Ukrainy. Drugą kategorię stanowią uchodźcy z Azji i Afryki, zwłaszcza z Bliskiego Wschodu, którzy aktualnie szukają w Europie lepszych warunków życia. W zasadzie są to migranci, których dopiero należy się spodziewać, gdyż w chwili obecnej ich liczba nie stanowi dla polityki społecznej istotnego problemu. Do tej pory największą grupę tego rodzaju uchodźców stanowią Czeczeńcy. Przybywają do Polski od 1995 roku. Ogólnie szacuje się, że przewinęło się ich przez terytorium Polski ok. 90 tys. Pozostało tylko od 7 do 8 tys., gdyż zdecydowana większość z nich wyjechała na Zachód ${ }^{3}$.

Wedle danych Urzędu ds. Cudzoziemców liczba posiadaczy polskich kart pobytu w roku 2015 wynosiła 211 869, w 2014 - 175 o6o, w 2013 - 121 219, w 2012 - 111 971, a w 2005 roku - naznaczonym początkiem obecności Polski w Unii Europejskiej - tylko $26259^{4}$. Zatem liczba ta w ostatnich latach gwałtownie wzrosła. Niemniej jednak należy zdawać sobie sprawę z tego, że informacja o liczbie cudzoziemców posiadających zezwolenia na pobyt to niepełny obraz imigracji do Polski5.

3 Wedle danych gromadzonych przez Urząd ds. Cudzoziemców w 2013 roku przybyło ich 12 326, w 1914 - 3 663, a w 2015 - 2554. Za: K. Zuchowicz, Polska przyjęła już ponad 80 tysięcy Czeczenów i wciąż przyjmuje następnych. Czy komuś to przeszkadza?, http://natemat.pl/155107,polska-przyjela-juz-blisko-9o-tysiecy-uchodzcow-z-czeczenii-dzis-zostala-ich-tylko-garstka-bo-nie-chcieli-u-nas-zostac (27.10.2017).

4 Za: J. Konieczna-Sałamatin, Migracja do Polski ws świetle danych urzędowych, http://www.i-see.org.pl/strona/uploads/ngrey/Documents/Analiza_danych_ urzedowych_JKs.pdf (12.11.2016).

5 Zob. Emn Europejska Sieć Migracyjna, Migracje do Polski w 2015 roku-głównie tendencje, https://emn.gov.pl/esm/aktualnosci/13512,Migracje-do-Polski-w-2015roku-glownie-tendencje.html (22.11.2016). 
Wśród przyjeżdżających do Polski migrantów trzeba zauważyć także grupę repatriantów, a także tych wszystkich, którzy pragną powrócić do ojczyzny po dłuższym pobycie za granicą, dokąd wyjechali zmuszeni niekorzystną dla siebie sytuacją ekonomiczną.

\section{Imigracja zarobkowa w Polsce}

Aktualnie przebywający w Polsce cudzoziemcy to przede wszystkim imigranci zarobkowi ${ }^{6}$. Wśród nich można wyróżnić trzy grupy: 1 . imigrantów zatrudnionych legalnie; 2. imigrantów pracujących nielegalnie; 3. imigrantów biznesowych.

Do pierwszej z nich należą przeważnie ci, którzy otrzymali zezwolenie na pobyt i pracę na podstawie zgłoszeń polskich przedsiębiorców lub w wyniku własnych starań czy też wykonują zadania kontraktowe. Wielu cudzoziemców przebywa w Polsce na podstawie wiz, z których znaczna część to wizy wydane w związku z wykonywaniem pracy. Niestety, na podstawie wiz trudno ustalić dokładnie, ilu cudzoziemców mieszka i pracuje w Polsce. Otóż istnieje możliwość wykonywania pracy bez konieczności uzyskiwania zezwolenia, a jedynie na podstawie zarejestrowanego oświadczenia o zamiarze powierzenia pracy cudzoziemcowi. Tego rodzaju możliwość dotyczy obywateli Armenii, Białorusi, Gruzji, Mołdawii, Rosji i Ukrainy. Nietrudno zauważyć, że zarejestrowanie wspomnianego wyżej oświadczenia o zamiarze powierzenia pracy cudzoziemcowi nie jest równoznaczne z tym, że ten

6 Zob. Ministerstwo Rodziny, Pracy i Polityki Społecznej, Informacja nt. zatrudniania..., dz.cyt.

7 Oświadczenia o zamiarze powierzenia pracy cudzoziemcowi pracodawca rejestruje w powiatowym urzędzie pracy. Na ich podstawie obywatele wspomnianych państw mogą wykonywać pracę bez urzędowego zezwolenia przez okres 6 miesięcy w ciągu kolejnych 12 miesięcy. Por. Ministerstwo Rodziny, Pracy i Polityki Społecznej, Informacja nt. zatrudniania..., dz. cyt. 
cudzoziemiec do Polski przyjechał i pracuje. Ponadto nie wszystkich posiadaczy wiz można zaliczyć do imigrantów, a nawet przeciwnie znaczna część z nich imigrantami nie zostaje ${ }^{8}$.

Do drugiej grupy należy zaliczyć imigrantów pracujących nielegalnie, nie wyłączając także pracy w tzw. szarej strefie. Wśród nich najwięcej jest obywateli Ukrainy. Zdaniem Bartosza Marczuka, podsekretarza stanu w Ministerstwie Rodziny, Pracy i Polityki Społecznej, aktualnie, tj. w połowie listopada 2016 roku, legalnie pracuje w Polsce okresowo od 350 do 500 tys. przybyszów z Ukrainy. Cała reszta imigrantów ukraińskich, a może ich być ok. 270 tys., pracuje nielegalnie. Obywatele Ukrainy znajdują pracę głównie w rolnictwie i ogrodnictwie, budownictwie, jako osoby sprzątające mieszkania i biura lub pełniące opiekę nad osobami starszymi lub chorymi.

Grupę imigrantów szczególnego rodzaju tworzą ci cudzoziemcy, którzy przyjeżdżają do Polski w celach zarobkowych jako ludzie biznesu. Jest to tzw. imigracja biznesowa, związana z ekspansją kapitału obcego do Polski. Jednak stanowi ona przedmiot zainteresowań nie tyle polityki społecznej jako takiej, lecz nade wszystko polityki gospodarczej. O znaczeniu tej grupy migracyjnej świadczy fakt istnienia w Polsce kilkudziesięciu tysięcy przedsiębiorstw zagranicznych, o które troszczy się co najmniej tyle samo cudzoziemców. Przykładowo W 2006 roku przedsiębiorstw zagranicznych było ok. 50 tys. i ta liczba do tej pory nie podlega większym wahaniom ${ }^{10}$. Dane Centralnego Ośrodka Informacji Gospodarczej według stanu z 30 września 2016

8 Por. Ministerstwo Rodziny, Pracy i Polityki Społecznej, Informacja nt. zatrudniania..., dz. cyt.

9 Zob. Nawet 270 tys. Ukraińców może pracować w Polsce nielegalnie. ZPP chce zmian, http://www.pulshr.pl/praca-tymczasowa/nawet-270-tys-ukraincow-moze-pracowac-w-polsce-nielegalnie-zpp-chce-zmian,32093.html (13.11.2016).

Zob. A. Rajkiewicz, Polityka społeczna..., dz. cyt., s. 310. 
roku wskazują, że w Polsce zarejestrowanych jest 50324 aktywnych spółek z udziałem kapitału zagranicznego ${ }^{11}$.

Ponadto można mówić o imigracji edukacyjnej. Do Polski najwięcej studentów przyjeżdża z krajów byłego Związku Sowieckiego, a zwłaszcza z Ukrainy. Obecnie (stan z października 2016 roku) w Polsce studiuje 57119 studentów zagranicznych ze 157 krajów, czyli o ponad 10 tys. więcej niż w roku poprzednim. Stanowią oni w tej chwili 4,1 proc. ogółu studentów (osiem lat temu było to zaledwie 0,6 proc., rok temu 3,1 proc.).

Nastąpił wzrost studiujących w Polsce obywateli Ukrainy. Według najnowszych danych Głównego Urzędu Statystycznego w roku akademickim 2016/2017 rozpoczęło studia 30589 studentów - czyli o 7197 więcej niż rok temu. Stanowią oni już ponad 53 proc. ogółu studentów zagranicznych w Polsce. Skokowy przyrost ich liczby spowodowany jest konsekwentną, dziesięcioletnią strategiczną obecnością marketingową i promocyjną polskich uczelni na tym rynku (głównie w ramach programu „Study in Poland”), jak i obecną trudną sytuacją polityczną i gospodarczą na Ukrainie ${ }^{12}$.

Drugą największą grupę studentów zagranicznych w Polsce stanowią obywatele Białorusi (jest ich 4615), Norwegowie (1581), Hiszpanie (1407) i Szwedzi (1291). W roku akademickim 2015/16 ponad 83 proc. ogółu studentów obcokrajowców przyjechało do Polski z Europy. W porównaniu ze średnią światową w Polsce uczy się niewielu studentów z Azji - jest ich 6896. Jednak należy zaznaczyć, że po raz pierwszy od pięciu lat obserwuje się w tej kategorii tendencję wzrostową.

11 Zob. Inwestorzy zagraniczni w Polsce, http://www.coig.com.pl/inwestorzy-zagraniczni-w-polsce.php (14.11.2016).

Zob. W Polsce studiuje 57119 studentów zagranicznych ze 157 krajów, „MegaBaza edukacyjna Perspektywy", http://www.perspektywy.pl/portal/index. php?option $=$ com_content $\& v i e w=$ article $\& i d=2899:$ w-polsce - studiuje $-57-119-$ studentow-zagranicznych-ze-157-krajow\&catid=22\&Itemid=119 (12.11.2016). 
Aktualnie w Polsce studiuje 846 Chińczyków, 505 Tajwańczyków, 896 Hindusów, 234 Wietnamczyków i 182 Malezyjczyków. Mimo wysiłków promocyjnych polskich uczelni wciąż niewielka jest liczba studentów z Ameryki Południowej (173, w tym z Brazylii - 82), Ameryki Północnej i Środkowej (1230) oraz Afryki (1197). W Polce studiują też studenci z Arabii Saudyjskiej (854) i Turcji (1205) ${ }^{13}$.

Na razie wciąż utrzymuje się wzrost zatrudnienia cudzoziemców w Polsce, w szczególności w zakresie podejmowania pracy bez zezwolenia - na podstawie oświadczenia podmiotu zatrudniającego o zamiarze powierzenia pracy cudzoziemcowi. Rok 2015 był rekordowy zarówno pod względem liczby wydanych zezwoleń na pracę cudzoziemca, jak i zarejestrowanych oświadczeń. Zezwoleń wydano 65786 , podczas gdy w 2010 roku ich liczba wynosiła tylko 36 622. Natomiast liczba zarejestrowanych oświadczeń wynosiła prawie 800 tys., podczas gdy w 2010 roku odnotowano ich ok. 180 tys. Dane z początku 2016 roku wskazują na kontynuację trendu wzrostowego. Zapotrzebowanie na pracę cudzoziemców rośnie w większości branż, szczególnie silny wzrost odnotowywany jest w budownictwie i transporcie. Coraz aktywniejszą rolę w zatrudnianiu cudzoziemców odgrywają też agencje zatrudnienia ${ }^{14}$.

Warto odnotować fakt, iż aktualnie, tj. w listopadzie 2016 roku, trwają prace nad nowelizacją ustawy o promocji zatrudnienia i instytucjach rynku pracy, która ma na celu wdrożenie do polskiego systemu prawnego dyrektywy Parlamentu Europejskiego i Rady 2014/36/UE z 26 lutego 2014 r. (tzw. dyrektywy w sprawie pracowników sezonowych). Proponowane zmiany zmierzają również do ograniczenia nadużyć

13 Zob. W Polsce studiuje..., dz. cyt.

14 Zob. Ministerstwo Rodziny, Pracy i Polityki Społecznej, Informacja nt. zatrudniania..., dz. cyt.; zob. także Ministerstwo Rodziny, Pracy i Polityki Społecznej, Cudzoziemcy pracujacy w Polsce - statystyki, http://www.mpips.gov.pl/analizy-i-raporty/cudzoziemcy-pracujacy-w-polsce-statystyki (22.11.2016). 
obecnych przepisów dotyczących rejestracji oświadczeń o zamiarze powierzenia pracy cudzoziemcowi oraz do monitorowania faktycznego zatrudniania cudzoziemców w Polsce. Chodzi o to, by zarządzanie migracjami zarobkowymi do Polski uczynić bardziej sprawnym. Jednak autorzy nowelizacji zapewniają, że starają się przestrzegać zasady, wedle której przeciwdziałanie nadużyciom nie powinno likwidować zalet obecnych przepisów. Projekt nowelizacji zachowuje dotychczasowe preferencje dla obywateli sześciu państw: Armenii, Białorusi, Gruzji, Mołdawii, Rosji i Ukrainy - obecnie korzystających z procedury uproszczonej odnośnie do zatrudnienia. Ułatwienia podyktowane są pozytywnymi doświadczeniami w ich integracji na polskim rynku pracy i w społeczeństwie. Mają być także wprowadzone korzystniejsze rozwiązania dla pracodawców regularnie i zgodnie z przepisami zatrudniających cudzoziemców na podstawie nowych przepisów.

\section{Imigracyjne dylematy}

Dla polityki społecznej największym wyzwaniem jest imigracja zarobkowa z Ukrainy. Nadal rośnie udział Ukraińców w liczbie wydanych zezwoleń i zarejestrowanych oświadczeń. W 2015 roku ich procentowy udział dotyczący liczby zezwoleń wynosił 77 proc., a odnośnie do zarejestrowanych oświadczeń - prawie 98 proc. Jest to wszakże realne wyzwanie, które domaga się odpowiednich regulacji państwa na rynku pracy, co nie jest łatwe z uwagi na wciąż utrzymującą się wysoką stopę bezrobocia pomimo tego, że w 2016 roku jest ona niższa niż w latach poprzednich. We wrześniu wyniosła 8,3, w sierpniu 8,4, a jeszcze w styczniu 10, $2^{15}$. Rzetelna interpretacja tych wskaźników

15 Za: Gus Portal Informacyjny, Stopa bezrobocia w latach 1990-2016, http://stat. gov.pl/obszary-tematyczne/rynek-pracy/bezrobocie-rejestrowane (16.11.2016). 
musi uwzględniać niesłabnącą emigrację zarobkową Polaków. Wyjazdy z Polski do pracy za granicą znacząco przyczyniają się do obniżenia stopy bezrobocia, która - wbrew temu, co się niekiedy sugeruje - niekoniecznie wynika ze wzrostu liczby nowych miejsc pracy.

Napływ imigrantów z krajów uboższych gospodarczo powoduje niekorzystną konkurencję na rynku pracy. Obywatelom Ukrainy opłaca się podjąć prace zlecone za wynagrodzeniem znacznie niższym aniżeli to, na które oczekują Polacy. Decyduje o tym kurs waluty ukraińskiej. Jest on bardzo korzystny dla tych, którzy pracują w Polsce i pobierają wynagrodzenie w walucie polskiej, którą następnie wymieniają na walutę własną, wydając zarobione pieniądze na Ukrainie. Dla polskiej polityki społecznej, zwłaszcza polityki zatrudnieniowej i polityki migracyjnej, jest to poważny dylemat. Do jakiego stopnia można narażać własnych obywateli na skrajnie niekorzystną pozycję na rynku pracy, spowodowaną konkurencją ze strony imigrantów? W sytuacji znacznego bezrobocia, sprzyjając imigracji zarobkowej, tolerując chociażby nielegalne zatrudnienia cudzoziemców w tzw. szarej strefie, skazuje się własnych obywateli na konieczność zarobkowej emigracji. Jest to dylemat, którego do tej pory nie udało się skutecznie przezwyciężyć i wygląda na to, że nie uda się to w najbliższej przyszłości. Albowiem - zgodnie z prognozami - fala imigrantów będzie nadal wzrastać.

Nie jest to wszakże jedyny dylemat związany z imigracją. Z przekazów medialnych wynika, że do Polski dociera coraz więcej imigrantów z Ukrainy. W samym tylko 2015 roku przybyło ich - według szacunków resortu pracy - od 300 do 500 tys. Choć większość z nich szuka uczciwej pracy, to jednak niektórzy stoją na bakier z prawem. Statystyki prowadzą do jednoznacznego wniosku: wraz z rosnącą liczbą przybyszów z Ukrainy rośnie przestępczość w Polsce. Jak informuje prasa, powołując się na oficjalne dane Ministerstwa Spraw Wewnętrznych i Administracji, jeszcze 5 lat temu o popełnienie przestępstw 
w Polsce było podejrzanych 493 Ukraińców. W 2014 roku ich liczba wzrosła już do 1084. W 2015 roku obywateli Ukrainy pozostających w konflikcie z prawem było 1315, a do połowy obecnego $-1030^{16}$. Nie bez znaczenia jest fakt, iż w więzieniach i aresztach w Polsce obecnie, to jest w 2016 roku, przebywa ok. 200 Ukraińców. To dwukrotnie więcej niż przed rokiem. Ponadto część imigrantów popada w konflikt z prawem, pracując np. w nielegalnych fabrykach papierosów prowadzonych przez różne gangi, w tym także polsko-ukraińskie ${ }^{17}$.

Warto jednak uświadomić sobie fakt, że pewien stopień przestępczości imigrantów jest czymś nieuniknionym. Niepokój może budzić dopiero skala tego rodzaju zjawiska. Wprawdzie statystyka jest pod tym względem niekorzystna odnośnie do Ukraińców, ale nie oznacza to jeszcze, że stanowią oni poważne zagrożenie dla porządku publicznego. Po prostu stanowią oni największą, i to wciąż powiększającą się, grupę imigrantów. Jeśli uwzględni się proporcje liczbowe w zestawieniu $\mathrm{z}$ innymi nacjami, to sytuacja wydaje się nie budzić większych obaw.

\section{Imigracyjne wyzwania}

Istnienia problemów związanych z imigracją nie można jednakże bagatelizować, tym bardziej, że dotyczą one egzystencji ludzi często skazanych na tułaczkę za chlebem, pozbawionych w swoich ojczystych krajach perspektyw na przyszłość. Zasada solidarności każe widzieć problem imigrantów jako jeden z najważniejszych priorytetów, który domaga się działań ze strony polityki społecznej. Powszechnie

16 Za: Imigranci nie szanuja prawa. Wraz z napływem pracowników ze wschodu rośnie przestępczość, „Bibuła. Pismo niezależne”, http://www.bibula.com/?p=91517 (21.11.2016).

17 Za: Imigranci nie szanuja prawa..., dz. cyt. 
uznawana i przyjmowana „filozofia” polityki społecznej wskazuje jasno na konieczność realizacji w odniesieniu do imigrantów - jak już była o tym mowa - trzech podstawowych celów. Pierwszym z nich jest troska o jak najlepsze warunki życia migrantów; drugim - pomoc w znalezieniu pracy; trzecim zaś - inicjatywy i działania zmierzające do ich integracji i adaptacji z nowym otoczeniem. Są to wyzwania bodaj najważniejsze. Nie można ich zlekceważyć, ale należy także pamiętać o celach polityki społecznej państwa realizowanych wobec własnych obywateli.

Wydaje się, iż pod tym względem niezwykłą trafnością odznacza się myśl kard. Stefana Wyszyńskiego, którą wyraził w swoim przemówieniu do duchowieństwa jeszcze w 1976 roku. Stanowi ona pewną wskazówkę o charakterze moralnym, niepozbawioną jednak inspiracji, którą można by odnieść wprost do polityki społecznej. Prymas Tysiąclecia powiedział:

Nie oglądajmy się na wszystkie strony. Nie chciejmy żywić całego świata, nie chciejmy ratować wszystkich. Chciejmy patrzeć w ziemię ojczystą, na której wspierając się, patrzymy ku niebu. Chciejmy pomagać naszym braciom, żywić polskie dzieci, służyć im i tutaj przede wszystkim wypełniać swoje zadanie - aby nie ulec pokusie „zbawiania świata” kosztem własnej ojczyzny. Przypomina mi się tak wspaniale przedstawiony w powieści Gołubiewa „Bolesław Chrobry” i Parnickiego "Srebrne orły” fragment. Oto cesarz Otto II kusi Bolesława Chrobrego, czyni go patrycjuszem rzymskim i chce go ściągnąć do Rzymu. Ale król nie dał się wyciągnąć z Polski, z ubogiego Gniezna, na forum rzymskie. Został w swoim kraju, bo był przekonany, że jego zadanie jest tutaj. Naprzód umocnić musi swoją ojczyznę, a gdy to zrobi, pomyśli o innych, o sąsiadach. Niestety, u nas dzieje się trochę inaczej - „zbawia” się cały świat, kosztem Polski. To jest zakłócenie ładu społecznego, które musi być 
co tchu naprawione, jeżeli nasza Ojczyzna ma przetrwać w pokoju, w zgodnym współżyciu i współpracy, jeżeli ma osiągać upragniony ład gospodarczy. Nieszczęściem jest zajmowanie się całym światem kosztem własnej Ojczyzny ${ }^{18}$.

Przywołana wypowiedź bazuje - oczywiście - na realiach historycznych lat siedemdziesiątych xx stulecia. Polska była wówczas krajem niewątpliwie uboższym aniżeli dzisiaj, niemniej jednak intuicja prymasa Wyszyńskiego zdaje się mieć wartość uniwersalną, ponadczasową. Owszem, imigrantom trzeba pomóc. Jest to poniekąd powinność moralna, a nawet religijna, o czym wciąż przypomina papież Franciszek, ale nie można tego czynić „kosztem własnej Ojczyzny”. Na przykład nie może być tak, że przyjmując imigrantów, własnych obywateli skazuje się na konieczność emigracji...

\section{Summary}

Polish social policy in the context of immigration: dilemmas and challenges

The problem of immigration of necessity involves social policy. It provides a natural context for research, and is practical for issues related to migration policy. The tasks of social policies usually include: equalizing life chances

18 Cyt. za: Prymas Wyszyński: Nie ulegajmy pokusie zbawienia świata kosztem własnej ojczyzny!, http://www.fronda.pl/a/prymas-wyszynski-nie-ulegajmy-pokusie-zbawienia-swiata-kosztem-wlasnej-ojczyzny,56699.html (20.11.2016).

19 Definicja za: Słownik wyrazów obcych, red. E. Sobol, Warszawa, 1997.

20 Więcej na ten temat: M. Sitek, Kryzys uchodźczy a kryzys instytucjonalny Unii Europejskiej, „Journal of Modern Science” 1(2016) nr 28, s. 458-462.

21 Przepływy migracyjne do Europy nasiliły się już 2014 r., zwłaszcza na szlaku środkowośródziemnomorskim. Zob. Komisja Europejska, Wspólny komunikat do Parlamentu Europejskiego i Rady „Stawić czoła kryzysowi uchodźczemu w Europie: rola Europejskiej Służby Działań Zewnętrznych", http://eur-lex.europa.eu/ legal-content/PL/ALL/?uri=CELEX:52015JCOO4O (15.1.2017).

22 Komisja Europejska, EU-Turkey Statement: Questions and Answers, http://europa. eu/rapid/press-release_MEMO-16-963_pl.htm (3.11.2017). 
of migrants, helping them be secure in their new place of residence and facilitating their integration into the local population. The present text is an attempt to look at the dilemmas and challenges faced by social policy in connection with the phenomenon of immigration in Poland.

The vast majority of people from abroad in Poland have the status of an economic immigrants. Among them, three groups can be identified: 1. Legally employed immigrants; 2 . Illegal immigrants; 3 . Business immigrants. In addition, there is educational immigration. Most students come to Poland from the former Soviet Union, especially Ukraine.

Work is continuing on the amendment of the Act on employment promotion and labor market institutions (as of November 2016 year). The proposed changes aim to: 1 . reduce abuse of the current rules concerning the registration of declarations of intention to entrust work to a foreigner, and 2. monitoring the actual employment of foreigners in Poland. The draft amendment retains the current preferences for the citizens of six countries: Armenia, Belarus, Georgia, Moldova, Russia and Ukraine - who currently benefit from a simplified procedure with respect to employment.

Keywords: migration, labor immigration, educational immigration, business immigration, employment of foreigners, social policy, migration policy 